\title{
Growth and grazing rates of the herbivorous dinoflagellate Gymnodinium sp. from the open subarctic Pacific Ocean
}

\author{
Suzanne L. Strom* \\ School of Oceanography WB-10, University of Washington, Seattle, Washington 98195, USA
}

\begin{abstract}
Growth, grazing and cell volume of the small heterotrophic dinoflagellate Gymnodinium $\mathrm{sp}$. isolated from the open subarctic Pacific Ocean were measured as a function of food concentration using 2 phytoplankton food species. Growth and ingestion rates increased asymptotically with increasing phytoplankon food levels, as did grazer cell volume; rates at representative oceanic food levels were high but below maxima. Clearance rates decreased with increasing food levels when Isochrysis galbana was the food source; they increased with increasing food levels when Synechococcus sp. was the food source. There was apparently a grazing threshold for ingestion of Synechococcus: below an initial Synechococcus concentration of $20 \mathrm{\mu gC} \mathrm{I}^{-1}$ ingestion rates on this alga were very low, while above this initial concentration Synechococcus was grazed preferentially. Gross growth efficiency varied between 0.03 and 0.53 (mean 0.21 ) and was highest at low food concentrations. Results support the hypothesis that heterotrophic dinoflageliates may contribute to controlling population increases of small, rapidly-growing phytoplankton species even at low, oceanic phytoplankton concentrations.
\end{abstract}

\section{INTRODUCTION}

Heterotrophic dinoflagellates can be a significant component of the microzooplankton in marine waters. In the oceanic realm, Lessard (1984) and Shapiro et al. (1989) found heterotrophic dinoflagellates to be abundant in the North Atlantic, while these organisms can be numerous at least seasonally in the subarctic North Pacific (Taylor \& Waters 1982, Strom \& Welschmeyer 1991, B. Booth pers. comm.). Nearshore waters can also support sizable populations of heterotrophic dinoflagellates (e.g. Gifford 1988, Weisse \& Scheffel-Möser 1990. Hansen 1991) which at times can be as large as populations of ciliated protozoans (Smetacek 1981, Garrison \& Buck 1989, Lessard 1991).

Despite their potential importance, there have been few experimental laboratory studies of heterotrophic dinoflagellates. Distinguishing photosynthetic from heterotrophic species of common marine genera such

- Present address: Marine Science Institute, University of Texas at Austin, Port Aransas, Texas 78373-1267, USA as Gymnodinium and Gyrodinium is difficult or impossible using older preservation and microscopy techniques; experimental emphasis has been on more easily recognizable and collectable microzooplankton groups such as tintinnid ciliates. Swimming and feeding behaviors of heterotrophic dinoflagellates, however, differ substantially from those of ciliated protozoans, and the 2 groups of organisms may have very different responses to a given set of environmental conditions.

Many species of heterotrophic dinoflagellates are known to feed herbivorously (e.g. Lessard \& Swift 1985, Jacobsen \& Anderson 1986, Gaines \& Elbrächter 1987, Buck et al. 1990). When abundant, such species may have a significant impact on phytoplankton populations. Lessard (1991) calculated that the dinoflagellate Oblea rotunda could have cleared up to $53 \%$ of the daily primary production following a spring bloom in Chesapeake Bay, while Sherr et al. (1991) determined that $>5 \mu \mathrm{m}$ flagellates (probably primarily dinoflagellates) cleared a larger proportion of the water in a salt marsh estuary than did the ciliate population in a 
third of their experiments. In Antarctic waters, herbivory by Gymnodinium sp. accounted for nearly all grazing losses to the natural phytoplankton assemblage in microcosm experiments (Bjørnsen \& Kuparinen 1991). Given that heterotrophic dinoflagellates may be at least seasonally abundant and active as herbivores, their behavioral responses comprise an important part of the behavior of the entire microzooplankton community,

In nutrient-rich areas of the open ocean, the mechanisms that control phytoplankton biomass are not well understood (e.g. Banse 1990, Martin et al. 1990). For the open subarctic Pacific in particular, a long history of oceanographic research centered on Weather Station $\mathrm{P}\left(50^{\circ} \mathrm{N}, 145^{\circ} \mathrm{W}\right)$ has indicated that phytoplankton biomass remains low and nearly constant year-round, in spite of high nutrient concentrations and seasonal increases in primary production (Miller et al. 1988 and referencos therein). Recently, it has been hypothesized that microzooplankton grazing is responsible for maintaining phytoplankton standing stocks at observed low levels (Evans \& Parslow 1985, Frost 1987, Miller et al. 1988). If true, individual microzooplankton species must have significant grazing rates at low natural food concentrations. Potential population growth rates must be nearly equivalent to those of phytoplankton to maintain low plant standing stocks in the face of increases in primary production. In this study, a herbivorous heterotrophic dinoflagellate was isolated from the open subarctic Pacific, and growth and grazing rates of this species were measured over a range of food concentrations. Grazer cell size and gross growth efficiency were also determined.

\section{MATERIALS AND METHODS}

Culture methods. The dinoflagellate was isolated from water collected at Station $\mathrm{P}$ in late September 1987. Water collected from the mixed layer using a Teflon-lined 301 Go-Flo bottle was placed in acidcleaned $(10 \% \mathrm{HCl})$, Milli-Q-rinsed 2 I polycarbonate bottles covered with one layer of neutral density screening and stored in an incubator cooled by flowing surface seawater during transit to shore (ca 3 d). Most bottles were enriched by additions of 2 or 3 species of cultured phytoplankton to encourage growth of herbivorous protozoans.

Laboratory isolation and culture maintenance procedures in general followed Gifford (1985). Protozoan culture medium was made by passing seawater (collected from the mixed layer at Station P) through a Gelman A/E filter followed by a $0.45 \mu \mathrm{m}$ Nuclepore filter in a $147 \mathrm{~mm}$ Plexiglas filter holder A peristaltic pump fitted with silicone tubing was used for filtration.
Trace metals and chelator were then added (Gifford 1985) and the medium was autoclaved and stored in 21 polycarbonate bottles.

Cultures were maintained in $250 \mathrm{ml}$ polycarbonate flasks that had been acid-cleaned $(10 \% \mathrm{HCI})$, Milli-Q rinsed, and autoclaved while containing about $150 \mathrm{ml}$ Milli-Q water. The dinoflagellate was kept at $12^{\circ} \mathrm{C}$ (= late summer mixed layer water temperature at Station P) on a $15 \mathrm{~h}$ light: $9 \mathrm{~h}$ dark cycle; irradiance was $\operatorname{dim}\left(\leq 5 \mu \mathrm{Ein} \mathrm{m}^{-2} \mathrm{~s}^{-1}\right)$. The food supply was a mixture of 4 phytoplankton species (Isochrysis galbana, Emiliania huxleyi, Micromonas pusilla, Synechococcus sp. [strain DC-2]) on which the grazer grew best during isolation in multi-well plates. Protozoa were fed every 5 to $6 \mathrm{~d}$ with exponential-phase phytoplankon cultures and were transferred every 2 to $3 \mathrm{wk}$. Care was taken to maintain Gymnodinium sp. stocks on relatively low levels of food to prevent possible adaptation to unnaturally high phytoplankton concentrations.

Phytoplankton were grown in $250 \mathrm{ml}$ borosilicate flasks on IMR medium (Eppley et al. 1967), with the exception of Synechococcus sp. and Emiliania huxleyi, which were grown on IMR medium diluted $1: 4$ with sterile filtered seawater. Cultures were maintained at $13^{\circ} \mathrm{C}$ (Synechococcus at $18^{\circ} \mathrm{C}$ ) on a $15 \mathrm{~h}$ light : $9 \mathrm{~h}$ dark cycle and were transferred every 2 wk to maintain exponential-phase growth.

Experimental design. Prior to the experiment, a large stock (2.5 l) of dinoflagellates was grown on the food species Isochrysis galbana (cell diameter $4.5 \mu \mathrm{m}$ ) and Synechococcus sp. (strain DC-2) (cell dimensions $1.2 \times 2.4 \mu \mathrm{m})$. Protozoan culture medium (140 ml) was added to each of 18 polycarbonate flasks $(250 \mathrm{ml})$, precleaned as above. Aliquots of late exponential phase I. galbana and Synechococcus cultures were added to each flask for nominal total phytoplankton concentrations ranging from 10 to $300 \mathrm{\mu gC} \mathrm{l}^{-1}$ (3 flasks per food concentration). At the time of experiment setup, Synechococcus contributed about one-third and $I$. galbana about two-thirds the total phytoplankton carbon. (This combination of food species yielded a higher dinoflagellate growth rate than any other paired combination of 1 . galbana, Synechococcus, Emiliania huxleyi, and Micromonas pusilla in preliminary experiments. The dinoflagellate would not grow when offered only a single food species.) Subsamples $(10 \mathrm{ml})$ of the Gymnodinium stock culture were then added to each flask for an initial grazer concentration of ca 40 cells $\mathrm{ml}^{-1}$ An additional 4 control flasks containing phytoplankton only were set up as above: 2 each at total

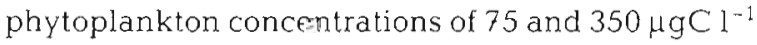

The experiment was carried out under conditions of light and temperature specified for grazer culture maintenance. Flasks were incubated on slowly rotating turntables ( $1 \mathrm{rpm}$ ) to ensure an even light field for 
all replicates and to minimize aggregation of phytoplankton foods. Dinoflagellates were acclimated to food concentrations for $42 \mathrm{~h}$, then initial, $24 \mathrm{~h}$, and $48 \mathrm{~h}$ samples were taken at approximately 13:00 h each day. Sampling procedure at each time point consisted of removing two $20 \mathrm{ml}$ subsamples from each flask and adding them to $0.5 \mathrm{ml}$ acid Lugol's (final preservative concentration $2 \%$ ) for grazer enumeration. An additional $5 \mathrm{ml}$ subsample was taken from each flask for epifluorescence slide preparation and enumeration of phytoplankton.

Heterotrophic dinoflagellate abundance was determined by placing 1 to $3 \mathrm{ml}$ from each Lugol-preserved subsample into an inverted microscope slide chamber and counting the entire slide contents with a Zeiss inverted microscope. The first 25 dinoflagellates encountered on one sample from each time point and food concentration were measured using an ocular micrometer.

Epifluorescence slides were prepared by placing 1 to $5 \mathrm{ml}$ from each $5 \mathrm{ml}$ subsample into a filtration tower and adding 3 drops $25 \%$ glutaraldehyde. Samples then were filtered onto black $0.2 \mu \mathrm{m}$ Nuclepore filters under gentle vacuum $(<200 \mathrm{~mm} \mathrm{Hg})$, rinsed with 0.45 $\mu \mathrm{m}$ filtered seawater, and mounted on glass slides using Cargill type B immersion oil. Filters were examined on a Zeiss epifluorescence microscope at either $500 \times$ (Isochrysis galbana) or $800 \times$ (Synechococcus sp.) with Zeiss filter set 477709 (BP 450-490 excitation filter, FT 510 beam splitter, and LP 520 barrier filter) using xenon lamp illumination. Under this illumination system I. Galbana fluoresces red and Synechococcus fluoresces yellow. Contents of either an ocular grid or the entire field of view (depending on cell density) were enumerated for random fields of view until a minimum of 50 cells (I. galbana) or 200 cells (Synechococcus) had been counted. In a few samples from the $48 \mathrm{~h}$ time point fewer cells were counted.

Phytoplankton growth and dinoflagellate clearance and ingestion rates were calculated according to the equations of Frost (1972) as modified by Heinbokel (1978) to account for growth of the dinoflagellate population during the experiment. Dinoflagellate growth was assumed to occur exponentially and was calculated for each incubation flask and time interval according to

$$
\mu\left(\mathrm{d}^{-1}\right)=\frac{1}{t} \ln \frac{N_{t_{2}}}{N_{t_{1}}}
$$

where $N_{t_{1}}$ and $N_{t_{2}}=$ grazer abundances at the beginning and end of each time interval, respectively. Grazing and growth rates, Gymnodinium cell volumes, and gross growth efficiencies (GGE = grazer biomass produced/phytoplankton biomass ingested) were all plotted against average phytoplankton concentration
$(<\mathrm{C}\rangle_{i}$ Frost 1972) for each time interval. Carbon content of the heterotrophic dinoflagellate and Isochrysis galbana were determined by measuring cells of each species with an ocular micrometer, calculating cell volumes using standard geometric formulae, and applying the equation of Strathmann (1967). Carbon content of Synechococcus was calculated using a value of $0.294 \mathrm{pgC} \mathrm{cell}^{-1}$ (Cuhel \& Waterbury 1984). Reported Gymnodinium growth rates and GGEs are carbon specific, taking into account changes in average grazer cell volume over time.

\section{RESULTS}

\section{Species description}

The heterotrophic dinoflagellate was identified as belonging to the genus Gymnodinium, in accordance with Dodge \& Lee (1985). Cells were athecate and spherical to slightly oblate, with the cingulum more-orless medially located. Cell diameter (specimens preserved in $2 \%$ acid Lugol's) was ca $12 \mu \mathrm{m}$, although cell size varied with feeding conditions (see below). The feeding mechanism of this species is not known; however, under epifluorescent illumination intact phytoplankton food cells were frequently observed inside the grazer, suggesting that it does not digest prey extracellularly by means of a pallium or peduncle. Gymnodinium sp. has proven very hardy in culture and can survive extended periods (at least $1 \mathrm{mo}$ ) of starvation.

\section{Growth rate}

Growth rates of both phytoplankton species were near zero under the low irradiance conditions of the incubations (avg. $=-0.001 \mathrm{~d}^{-1}$ for Isochrysis galbana, $-0.0003 d^{-1}$ for Synechococcus sp.). Parameters of the numerical response for Day 1 (Fig. 1A) were estimated using a Monod model:

$$
\mu=\mu_{\max }\left[\frac{P}{K_{p}+P}\right]
$$

where $\mu_{\max }=$ maximum specific growth rate; $P=$ phytoplankton concentration; $K_{p}=$ half-saturation constant for growth ( $P$ at $\left.\mu_{\max } / 2\right)$. The model predicted a $\mu_{\max }$ of $0.84 \mathrm{~d}^{-1}$ for Gymnodinium, slightly higher than the maximum observed growth rate of $0.75 \mathrm{~d}^{-1}$, and a $K_{\mathrm{p}}$ of $19.8 \mu \mathrm{gC} \mathrm{I}^{-1}$.

Growth rate versus food concentration data for Day 2 of the experiment did not follow the expected hyperbolic pattern (Fig. 1B). Growth rates at low food concentrations were consistently higher on Day 2 than on Day 1. 

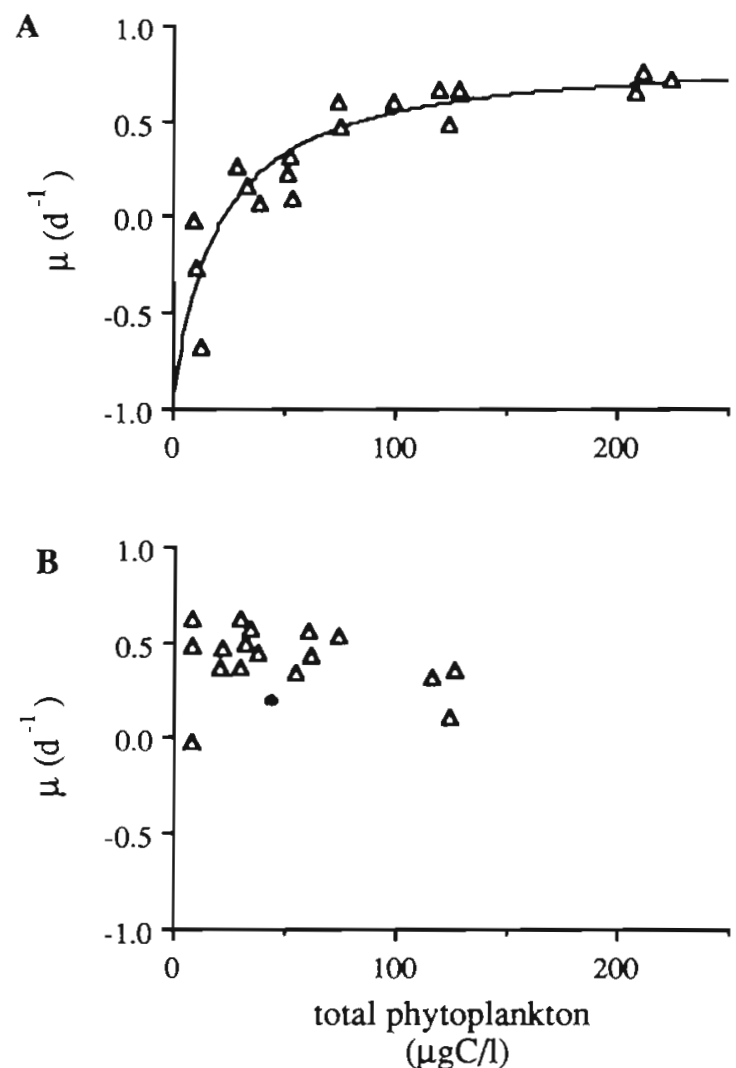

Fig. 1. Gymnodinium sp. Growth rate as a function of average food concentration. (A) Day 1 (data fit to Monod model);

(B) Day 2

\section{Cell volume}

Gymnodinium sp. cell volume exhibited the same hyperbolic relationship to food concentration as did Day 1 growth rate (Fig. 2), ranging from a low of 600 $\mu \mathrm{m}^{3}$ to a maximum of $1200 \mu \mathrm{m}^{3}$. Maximum cell volume as predicted by a Monod model fit to the data was $1111 \mu \mathrm{m}^{3}$

\section{Grazing rate}

When fed a mixture of Isochrysis galbana and Synechococcus sp., Gymnodinium sp. exhibited total clearance rates ranging from 0.19 to $1.64 \mu \mathrm{lnd} \mathrm{in}^{-1} \mathrm{~h}^{-1}$ and total ingestion rates ranging from 1.0 to $51.0 \mathrm{pgC}$ ind. $\mathrm{h}^{-1}$. Maximum volume-specific clearance (body volumes cleared body volume $e^{-1} \mathrm{~h}^{-1}$ ) was $1.8 \times 10^{6} \mathrm{~h}^{-1}$, while maximum carbon-specific ingestion (phytoplankton carbon ingested body carbon ${ }^{-1} \mathrm{~h}^{-1}$ ) was 0.41 $h^{-1}$, the latter calculated using the volume: carbon conversion factor of Strathmann (1967) for determination of Gymnodinium carbon content. There is some

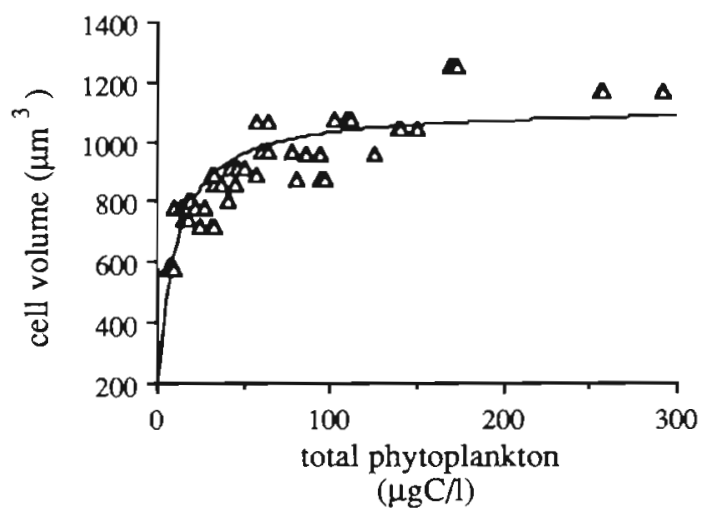

Fig. 2. Gymnodinium sp. Cell volume as a function of average food concentration (data fit to Monod model)

evidence that heterotrophic dinoflagellates may have higher carbon densities than photosynthetic flagellates. Carbon-specific ingestion calculated using a carbon density of $0.3 \mathrm{pg} \mu^{-3}$, determined for the heterotrophic dinoflagellate Protoperidinium parvum (Jacobson 1988), gave a maximum of $0.19 \mathrm{~h}^{-1}$.

Clearance and ingestion rates on Isochrysis galbana from Days 1 and 2 of the experiment are grouped

A

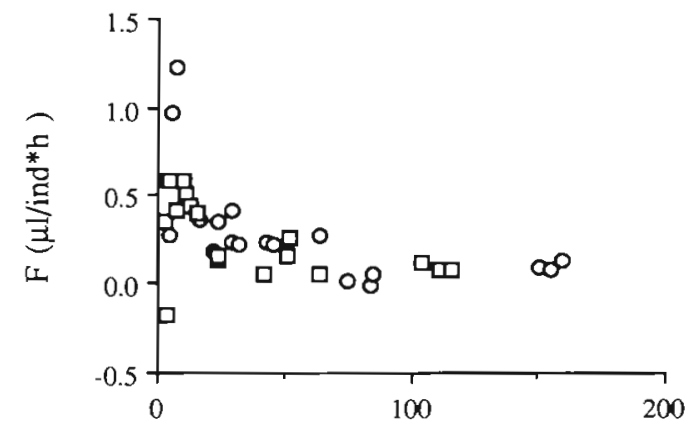

B

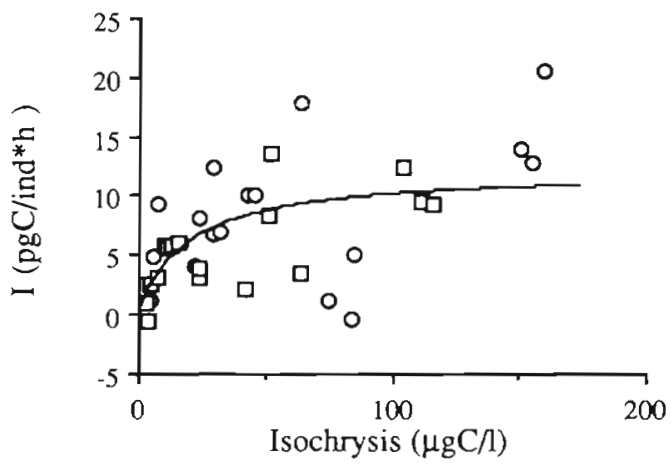

Fig. 3. Gymnodinium sp. Clearance (A) and ingestion (B) rates as a function of average food concentration for individuals grazing on Isochrysis galbana. (O) Day $1 ;$ (D) Day 2. (B) Data fit to Monod model 
(there were no obvious differences between days). Clearance rates decreased sharply with food concentration up to ca $25 \mu \mathrm{gC} \mathrm{l}^{-1}$, then decreased gradually with increasing food levels, reaching a minimum of ca $0.1 \mu$ ind $^{-1} \mathrm{~h}^{-1}$ (Fig. 3A). Ingestion of I. galbana (Fig. $3 \mathrm{~B}$ ) increased to a maximum of $12.1 \mathrm{pgC}$ ind ${ }^{-1} \mathrm{~h}^{-1}$ as predicted by a Monod model fit to the data, with $K_{p}=$ $19.2 \mu \mathrm{gCl}^{-1}$.

Grazing by Gymnodinium sp. on Synechococcus sp. differed on Days 1 and 2 of the experiment, so data are presented separately. Clearance rates on Day 1 varied at the lowest food concentrations but generally were near 0 below $20 \mu \mathrm{g}$ phytoplankton $\mathrm{C}^{-1}$, then increased linearly to $0.5 \mu \mathrm{l}$ ind $^{-1} \mathrm{~h}^{-1}$ at the highest food concentrations (Fig. 4A). On Day 2, clearance rates from flasks with low initial Synechococcus concentrations were still near 0, while rates from flasks with high initial Synechococcus concentrations ranged from 0.6 to $0.8 \mu \mathrm{l}$ ind..$^{-1} \mathrm{~h}^{-1}$ (Fig. $4 \mathrm{~B}$ ). This was in spite of the fact that average Synechococcus concentrations in these latter flasks were very low $\left(<15 \mathrm{\mu gC}^{-1}\right)$ on Day 2 .

The same pattern was observed for Gymnodinium $\mathrm{sp}$. ingestion of Synechococcus sp. (Fig. 5). Ingestion

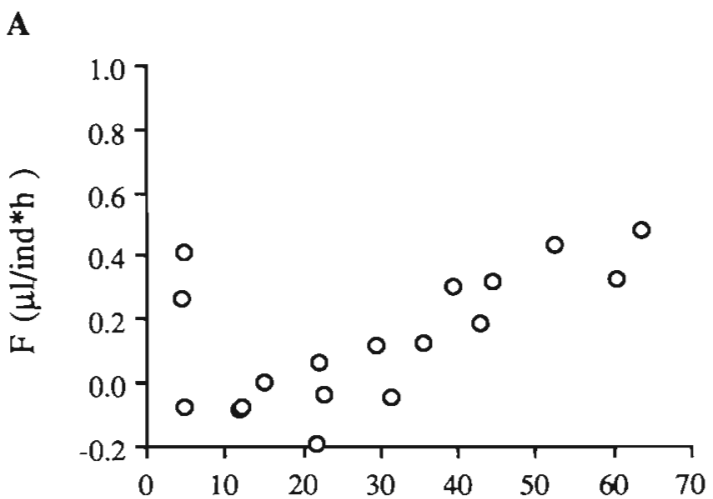

B

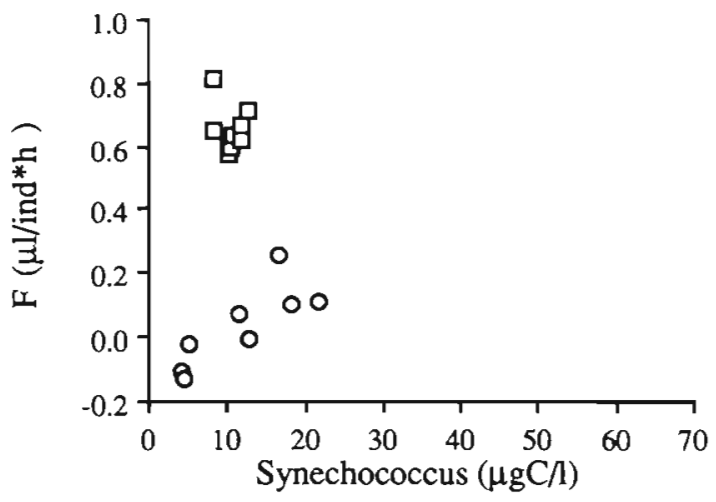

Fig. 4. Gymnodinium sp. Clearance rate as a function of average food concentration for individuals grazing on Synechococcus on Day 1 (A) and Day 2 (B). Day 2: (O) initial Synechococcus concentration $<20 \mu \mathrm{gC} \mathrm{l}^{-1}$; (口) initial Synechococcus concentration $>20 \mu \mathrm{gC}^{-1}$

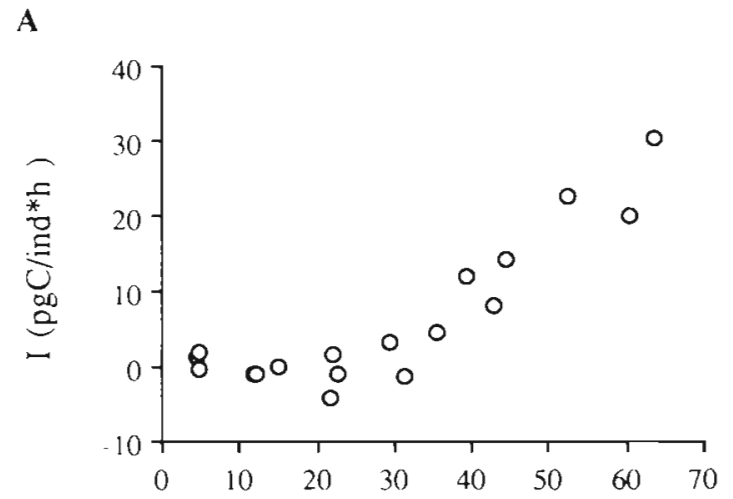

B

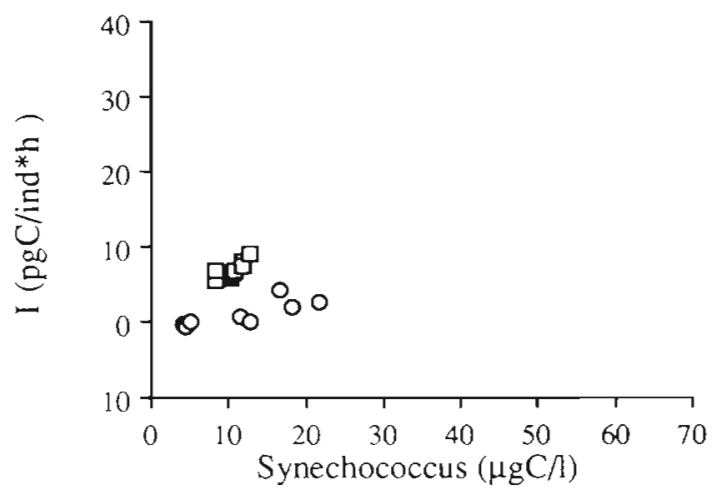

Fig. 5. Gymnodinium sp. Ingestion rate as a function of average food concentration for individuals grazing on Synechococcus sp. on Day 1 (A) and Day 2 (B). Day 2: (O) initial Synechococcus concentration $<20 \mathrm{\mu gC} \mathrm{1}^{-1}$ : (口) initial Synechococcus concentration $>20 \mu \mathrm{gCl}^{-1}$

rates were very low in any flask in which the initial Synechococcus concentration was below $20 \mu \mathrm{gC}^{-1}$. Above this initial food level, ingestion rate increased linearly with food concentration on Day 1, reaching a maximum of $30.4 \mathrm{pgC}$ ind. ${ }^{-1} \mathrm{~h}^{-1}$. Ingestion ranged from 5.4 to 9.2 pgC ind..$^{-1} \mathrm{~h}^{-1}$ on Day 2.

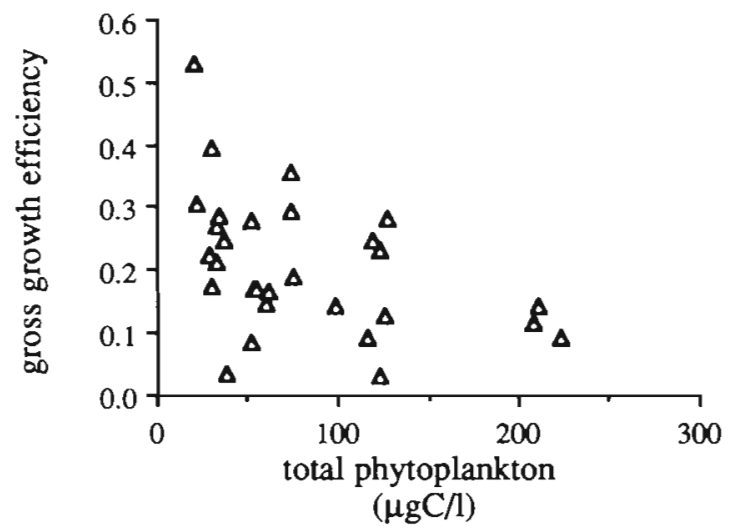

Fig. 6. Gymnodinium sp. Gross growth efficiency as a function of average food concentration 


\section{Gross growth efficiency}

Gymnodinium sp. GGEs exhibited a great deal of variability (Fig. 6), ranging from 0.03 to 0.53 with a mean of $0.21(\mathrm{SD}=0.11 ; \mathrm{n}=29)$. Maximum GGE appeared to be a function of food concentration, with the highest value of 0.53 observed at a total phytoplankton concentration of $20 \mu \mathrm{gCl}^{-1}$ and low values of 0.09 to 0.14 observed at total phytoplankton concentrations $>200 \mu \mathrm{gC} \mathrm{l}^{-1}$.

\section{DISCUSSION}

Gymnodinium sp. growth rates reported here must be interpreted very cautiously. Rates were based on only 2 time points, initial and final, and could easily be biased by experimental error. Also, the $24 \mathrm{~h}$ time interval between samples may have been too long, such that critical portions of the exponential growth curve could have been missed. Given the paucity of data on heterotrophic dinoflagellates, however, it was decided that the data should be presented, at least for comparison with similarly-collected data for other protist species. Gymnodinium exhibited a maximum growth rate of 0.7 $\mathrm{d}^{-1}$, reached at a concentration (critical concentration) of ca $80 \mu \mathrm{gCl}^{-1}$ on Day 1 of the experiment. Growth rates reported for other herbivorous dinoflagellates are similar, but critical concentrations are much higher (Table 1). Critical concentration differences may be due to differences in feeding mechanism, suitability of prey species, or isolation location (oceanic species may be adapted to lower food levels). When adjusted to $12{ }^{\circ} \mathrm{C}$, reported maximum growth rates of microflagellates and ciliates are consistently higher than those of dinoflagellates (Table 1). It is not known whether this observation is generally true, perhaps owing to differences in feeding mechanism among the 3 groups of organisms, or whether the discrepancy is due to the small number of species thus far investigated.

The maximum observed Gymnodinium growth rate of $0.7 \mathrm{~d}^{-1}$ is approximately equal to growth rates determined for mixed layer phytoplankton at Station P. Average phytoplankton growth rates during spring and summer 1984, measured using 2 different techniques, ranged from 0.63 to $0.68 \mathrm{~d}^{-1}$ (Booth et al. 1988, Miller et al. 1988). During September 1987, when Gymnodinium was collected, pigment-specific phytoplankton growth rates as measured by the seawater dilution technique ranged from 0.07 to $0.59 \mathrm{~d}^{-1}$ (Strom \& Welschmeyer 1991).

Dinoflagellate growth rates were high at relatively low phytoplankton concentrations, especially during Day 2 of the experiment. Again, these data must be interpreted cautiously, especially as decreases in phytoplankton concentration were larger during Day 2 than during Day 1 and it is less certain that the grazers were in a state of balanced growth. If real, the increased growth rate in low food treatments between Days 1 and 2 (Fig. 1) suggests that the grazer may have become gradually conditioned to low food concentrations over the course of the experiment. During Day 2, growth rates were maximal even at average phytoplankton concentrations of $10 \mu \mathrm{gC} \mathrm{l}^{-1}$. Upper watercolumn algal carbon concentrations at Station $\mathrm{P}$ ranged from 1 to $24 \mu \mathrm{g} \mathrm{l}^{-1}$ in May and August 1984 (Booth et al. 1988), and during 1987 - 88 ranged up to 50 $\mu \mathrm{g} \mathrm{l}^{-1}$ (Booth pers. comm.). Cells $<5 \mu \mathrm{m}$ in size accounted for a large fraction of this biomass and thus may have been available to small protozoan grazers. In as much as Gymnodinium is representative of open subarctic microzooplankton species, sufficient concentrations of phytoplankton are present in the open subarctic Pacific to support high rates of protozoan growth. If phytoplankton biomass begins to increase, high growth rates of individual protozoan species should enable these grazer populations to keep pace with incipient blooms.

The cell volume of the heterotrophic dinoflagellate Gymnodinium was observed to vary by a factor of 2 over the range of phytoplankton concentrations employed in this experiment. While the relationship between grazer cell volume and food concentration (Fig. 2) resembled that between growth rate and food concentration (Fig. 1A), there was no direct relationship between grazer cell volume and growth rate. The same finding has been reported for the microflagellate Pseudobodo sp. grazing on the prasinophyte Micromonas pusilla (Parslow et al. 1986). Goldman \& Dennet (1990) determined that the microflagellate Paraphysomonas imperforata could adjust its cell volume about 5 -fold when fed a range of prey types, becoming very small when bacteria were the food source and larger when large phytoplankton species were offered. They theorized that feeding by direct interception is most efficient when the difference between predator and prey size is minimized. This hydrodynamic explanation, however, does not seem to apply in the present case: Gymnodinium cell volume apparently increased as Synechococcus (the smaller of the 2 food species) made up a progressively larger fraction of the diet (Fig 7A). Alternatively, since a positive relationship was observed between Gymnodinium cell volume and total phytoplankton ingestion (Fig. 7 B), cell-volume changes in this species may simply reflect the amount of food contained within grazer food vacuoles at any given time. The average number of cells contained in a grazer should increase with food concentration until digestion, rather than encounter rate or rate of phagocytosis, limits ingestion. 
Table 1. Growth rates and critical concentrations for various species of protozoans feeding herbivorously. Taxonomic affiliation: $\mathrm{D}=$ heterotrophic dinoflagellate; $\mathrm{MF}=$ microflagellate; $\mathrm{T}=$ tintinnid ciliate $\mathrm{A}=$ aloricate ciliate. nd = not determined

\begin{tabular}{|c|c|c|c|c|c|c|c|}
\hline Grazer & $\begin{array}{l}\text { Taxonomic } \\
\text { affiliation }\end{array}$ & $\begin{array}{l}\text { Temp. } \\
\left({ }^{\circ} \mathrm{C}\right)\end{array}$ & Food(s) & $\frac{\mu_{\max }}{\left(d^{-1}\right)}$ & $\begin{array}{l}\mu_{\max } \\
\text { adjusted } \\
\left(\mathrm{d}^{-1}\right)\end{array}$ & $\begin{array}{l}\text { Critical } \\
\text { conc } \\
\left(\mu g \mathrm{Cl}^{-1}\right)\end{array}$ & Reference \\
\hline \multicolumn{8}{|l|}{ Flagellates } \\
\hline Gymnodinium sp. & $\mathrm{D}$ & 12 & $\begin{array}{l}\text { Isochrysis galbana }+ \\
\text { Synechococcus sp }\end{array}$ & 0.7 & 0.7 & 80 & This study \\
\hline $\begin{array}{l}\text { Gymnodinium sp. } \\
\text { (field population) }\end{array}$ & $\mathrm{D}$ & 1 & $\begin{array}{l}\text { Naturally occurring } \\
\text { phytoplankton }\end{array}$ & 0.3 & 0.6 & 250 & $\begin{array}{l}\text { Bjørnsen \& } \\
\text { Kuparinen (1991) }\end{array}$ \\
\hline $\begin{array}{l}\text { Oxyrrhis } \\
\text { marina }\end{array}$ & $\mathrm{D}$ & 20 & $\begin{array}{l}\text { Phaeodactylum tricomutum } \\
\text { I. galbana } \\
\text { Dunaliella tertiolecta }\end{array}$ & $\begin{array}{l}1.3 \\
0.8 \\
0.8\end{array}$ & $\begin{array}{l}0.8 \\
0.5 \\
0.5\end{array}$ & nd & Goldman et al. (1989) \\
\hline $\begin{array}{l}\text { Protoperidinium } \\
\text { hirobis }\end{array}$ & $\mathrm{D}$ & 20 & Leptocylindricus danicus & 1.2 & 0.7 & 1250 & Jacobson (1987) \\
\hline $\begin{array}{l}\text { Polykrikos } \\
\text { kofoidii }\end{array}$ & $\mathrm{D}$ & nd & Scrippsiella trochoidea & 0.7 & - & 450 & Gaines (1988) \\
\hline $\begin{array}{l}\text { Oxyrrhis } \\
\text { marina }\end{array}$ & $\mathrm{D}$ & nd & D. tertiolecta & 0.7 & - & 175 & \\
\hline $\begin{array}{l}\text { Paraphysomonas } \\
\text { imperforata }\end{array}$ & MF & 24 & $\begin{array}{l}\text { D. tertiolecta } \\
\text { Chlorella stigmataphora } \\
\text { C. capsulata } \\
\text { I. galbana } \\
\text { Porphyridium sp } \\
\text { P. tricornutum }\end{array}$ & $\begin{array}{c}2.4 \\
2.4 \\
2.3 \\
2.4 \\
2.4 \\
2.5-3.5\end{array}$ & $\begin{array}{c}1.1 \\
1.1 \\
1.0 \\
1.1 \\
1.1 \\
1.1-1.6\end{array}$ & nd & $\begin{array}{l}\text { Goldman \& Caron } \\
(1985)\end{array}$ \\
\hline Pseudobodo sp. & MF & 18 & Micromonas pusilla & 2.0 & 1.4 & nd & Parslow et al. (1986) \\
\hline \multicolumn{8}{|l|}{ Ciliates } \\
\hline $\begin{array}{l}\text { Tintinnopsis cf. } \\
\text { acuminata }\end{array}$ & $\mathrm{T}$ & 18 & $\begin{array}{l}\text { 1. galbana }+ \\
\text { Monochrysis lutheri }\end{array}$ & 1.4 & 1.0 & 50 & Heinbokel (1978) \\
\hline $\begin{array}{l}\text { Eutintinnus } \\
\text { pectinis }\end{array}$ & $\mathrm{T}$ & 18 & $\begin{array}{l}\text { I. galbana }+M \text {. Jutheri }+ \\
\text { D. tertiolecta }\end{array}$ & 1.4 & 1.0 & 80 & \\
\hline $\begin{array}{l}\text { Helicostomella } \\
\text { subulata }\end{array}$ & $\mathrm{T}$ & 18 & 1. galbana $+D \cdot$ tertiolecta & 0.8 & 0.6 & 60 & \\
\hline Favella sp. & $\mathrm{T}$ & 15 & Heterocapsa triquetra & 1.1 & 0.9 & 95 & Stoecker et al. (1983) \\
\hline $\begin{array}{l}\text { Tintinnopsis } \\
\text { acuminata }\end{array}$ & $\Upsilon$ & $15-25$ & I. galbana & $1.3-2.0$ & $1.1 \cdots$ & 100 & Verity (1985) \\
\hline $\begin{array}{l}\text { Tintinnopsis } \\
\text { vasculum }\end{array}$ & $\mathrm{T}$ & $5-15$ & Dicrateria inornata & $0.5-1.1$ & $0.9^{\bullet}$ & 120 & \\
\hline $\begin{array}{l}\text { Lohmaniella } \\
\text { spiralis }\end{array}$ & A & $15-23$ & $\begin{array}{c}\text { Naturally occurring } \\
\text { particulate matter }\end{array}$ & 1.0 & 0.9 & nd & Rassoulzadegan (1982) \\
\hline $\begin{array}{l}\text { Strombidium } \\
\text { reticulatum }\end{array}$ & $A$ & 12 & Pyramimonas sp. & 0.9 & 0.9 & 450 & Jonsson (1986) \\
\hline $\begin{array}{l}\text { Lohmaniella } \\
\text { spiralis }\end{array}$ & A & 12 & Pyramimonas sp & 1.0 & 1.0 & 450 & \\
\hline Balanion sp. & $A$ & 15 & H. triquetra & 2.2 & 1.9 & nd & Stoecker et al. (1986) \\
\hline
\end{tabular}


A

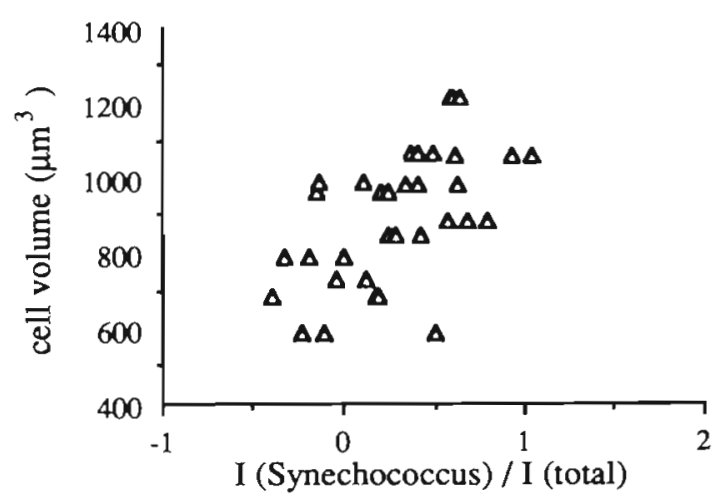

B

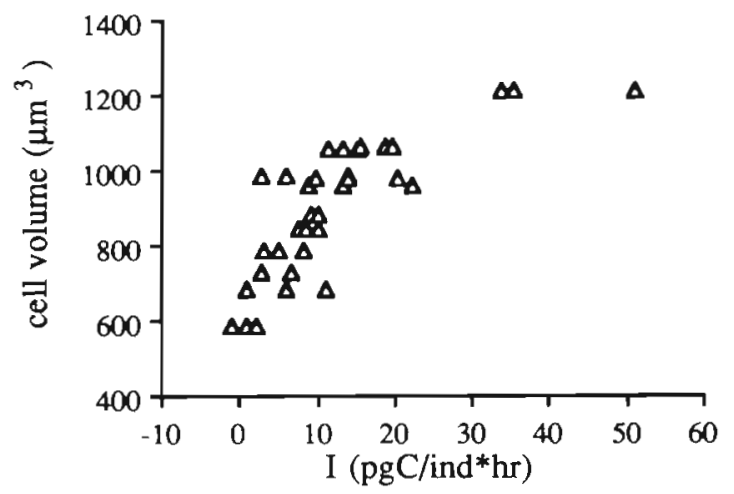

Fig. 7. Cell volume of Gymnodinium sp. versus Synechococcus sp. as a fraction of diet (A) and total phytoplankton ingestion $(B)$

Maximum volume-specific clearance rates for the heterotrophic dinoflagellate Gymnodinium sp. are higher than maximum rates observed for larger herbivorous protozoans, but appear reasonable given the small size of this grazer (Fig. 8) Clearance rates for the dinoflagellate Oxyrrhis marina, shown for comparison, appear anomalously low. Reported clearance rates for $O$. marina may not represent true maxima achievable by the organism at lower food concentrations. Alternatively, this species may employ a different feeding mechanism than Gymnodinium. O. marina appears to seek out and capture prey cells by extension of a thin filament (Goldman et al. 1989). Calculation of clearance rates may not be appropriate for this class of grazer, in which the capacity to ingest relatively large prey cells compensates for the inability to process large volumes of water. It is not known whether Gymnodinium feeds by utilizing a capture filament or, like chrysomonad microflagellates, by entrainment of food cells into a water current (e.g. Fenchel 1982).

Maximum carbon-specific ingestion for Gymnodinium is comparable to rates reported for other herbi- vorous protozoa (Fig. 8 references), given the smaller size of this grazer. The maximum carbon-specific ingestion rate of $0.19 \mathrm{~h}^{-1}$ (based on a relatively high Gymnodinium cell carbon content) is compatible with a growth rate of $0.7 \mathrm{~d}^{-1}$ and a GGE of 0.15 , both typical values for this grazer feeding at high food concentrations (Figs. $1 \& 6$ ).

Clearance and ingestion of Isochrysis galbana by Gymnodinium exhibited a classic relationship to food concentration (Fig. 3), with clearance reaching a minimum and ingestion a maximum at 40 to $50 \mathrm{\mu g}$ 1. galbana $\mathrm{C}^{-1}$. Similar functional response curves have been obtained for a number of ciliate species (Heinbokel 1978, Fenchel 1980, Scott 1985, Verity 1985, Jonsson 1986). Maximum clearance rates on $I$. galbana and Synechococcus were similar $(0.8$ to $1.2 \mu \mathrm{l}$ ind ${ }^{-1} \mathrm{~h}^{-1}$ ), but maximum ingestion rates on Synechococcus were higher than rates on $I$. galbana (30 and 20 $\mu \mathrm{gC}$ ind. ${ }^{-1} \mathrm{~h}^{-1}$, respectively).

Clearance and ingestion rates as a function of food concentration for Gymnodinium sp. feeding on Synechococcus sp. exhibited an unusual pattern. Apparently there was no grazing on Synechococcus until initial concentrations of this species were $>20$ $\mu \mathrm{gC}^{-1}$ (Fig. 5). At initial concentrations above this level, ingestion gradually increased with food concentration; rates remained high even when Synechococcus concentrations were reduced well below the initial threshold level of $20 \mu \mathrm{gC}^{-1}$ on Day 2 of the

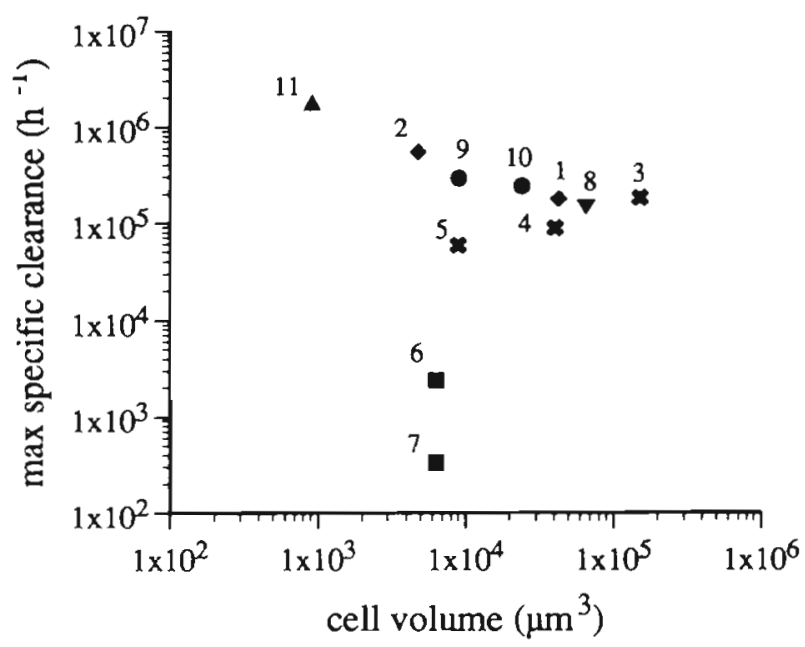

Fig. 8. Maximum volume-specific clearance rates of herbivorous Protozoa. 1, Tintinnopsis vasculum; 2 , T. acuminata ( Verity 1985j; 3, Lohmaniella spiralss; 4, Strombidum reticulatum; 5, S. vestitum ( $\mathbf{x}$ : Jonsson 1986); 6, Oxyrrhis marina fed Isochrysis galbana; 7, O. marina fed Phaeodactylum tricornutum (G: Goldman et al. 1989); 8, Lohmanjella spirals ( $\mathbf{*}$ : Rassoulzadegan 1982); 9, T. cf. acuminata; 10, Helicostomella subulata (O: Heinbokel, 1978); 11. Gymnodinium sp. 
A

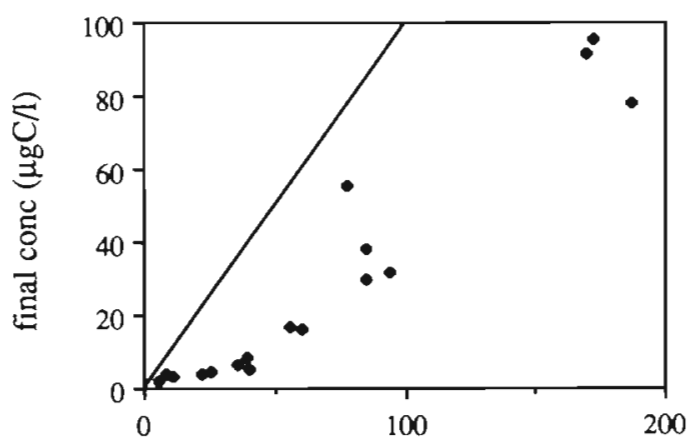

B

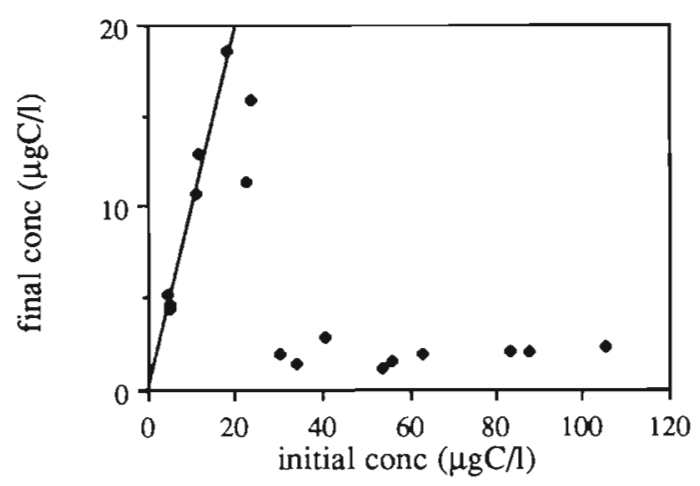

Fig. 9. Initiâl versus final concentration of Isochrysis galbana (A) and Synechococcus sp. (B). Solid lines represent equality (no change in concentration during experiment). I. galbana was grazed at all initial concentrations (all points fall below line), while Synechococcus was not grazed untıl initial concentrations exceeded $20 \mu \mathrm{C}^{-1}$

experiment (Fig. 9). An identical result was obtained for the flagellate Paraphysomonas imperforata feeding on Dunaliella tertiolecta both alone and in a food mixture (Goldman \& Dennett 1990, their Fig. 6B), although the apparent threshold concentration for $P$. imperforata was very high $\left(11700 \mathrm{\mu gCl}^{-1}\right)$

The classic definition of a grazing threshold is the food concentration below which it is energetically unrewarding for a grazer to continue attempting to gather food (Frost 1975). The energy required to create feeding currents outweighs that gained from ingestion of the occasional phytoplankter, and the grazer goes into a reduced-activity or non-feeding mode. However, alternative types of grazing thresholds may be envisioned in which it is energetically unrewarding to either ingest or digest cells of certain species at low food concentrations. Perhaps certain structural or enzymatic modifications are necessary before a herbivore can feed on a given phytoplankton species effectively. Once these modifications are made, it would be energetically feasible for the herbivore to graze this phytoplankton species even at very low concentrations. Grazing thresholds of the latter type may not be apparent when grazers are offered only a single prey species.

Euphotic zone concentrations of Synechococcus spp. in the natural environment of the subarctic Pacific are consistently lower than the Gymnodinium threshold level of $20 \mathrm{\mu gCl}^{-1}$, ranging from $<1$ to about $15 \mathrm{\mu gCl}^{-1}$ (Booth et al. 1988, Booth pers. comm.). Once grazing is initiated, Gymnodinium can effectively consume Synechococcus at these low levels (Fig. 4B); perhaps transient peaks in prey abundance occur which suffice to trigger the grazing response. Alternatively, Gymnodinium may not be an important consumer of Synechococcus in this ocean region.

Prey selection by Gymnodinium was dependent on initial prey concentration (Fig. 10). In flasks with an initial phytoplankton concentration $<75 \mathrm{\mu gCl}^{-1}$ (initial Synechococcus concentration $<25 \mu \mathrm{gC} \mathrm{I}^{-1}$ ) Isochrysis galbana was always ingested in greater proportion than would be predicted by its relative abundance. In flasks with higher initial food concentrations, Synechococcus was generally the preferred prey species. In other words, once significant grazing on Synechococcus commenced, this species was grazed preferentially. These findings contrast with those of Heinbokel (1978), who observed no selective grazing by Eutintinnus pectinnus under conditions of low food concentration, preferential ingestion of $I$. galbana occurring only when average food concentration exceeded $60 \mathrm{\mu gCl}^{-1}$. The dynamics of prey selection by protozoan grazers may depend on whether there exists a threshold feeding response for any of the prey species available. Additionally, as suggested by Verity (1991), selective ingestion may be determined by the nutritional quality of the entire spectrum of potential prey species.

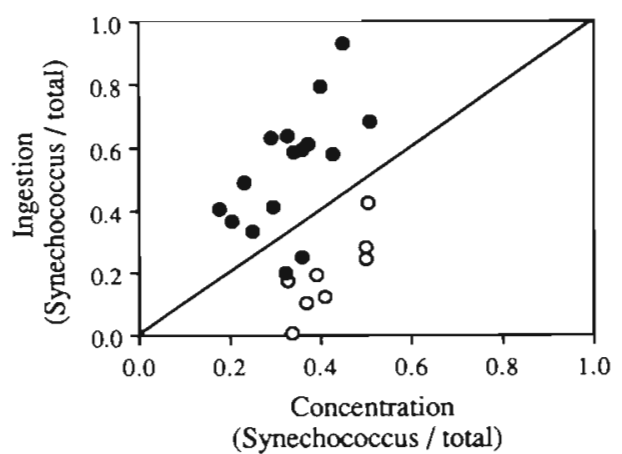

Fig. 10. Gymnodinium sp. Ingestion of Synechococcus as a fraction of total ingestion versus initial Synechococcus availability. Solid line represents no feeding preference (ingestion directly proportional to relative abundance of prey species). (O) Initial phytoplankton concentration $<75 \mu \mathrm{gC} \mathrm{l}^{-1}$ (initial Synechococcus concentration $\left.<25 \mathrm{\mu gCl}^{-1}\right)$; $(1)$ initia] phytoplankton concentration $>75 \mu \mathrm{gC} \mathrm{l}^{-1}$ (initial Synechococcus concentration $>25 \mu \mathrm{gC} \mathrm{l}^{-1}$ ) 
GGEs determined for Gymnodinium are within the range of values reported for other heterotrophic protozoans, both herbivorous and bacterivorous (summarized by Caron \& Goldman 1990). The tendency for protozoan GGEs to decrease at high food concentrations has been noted for a number of ciliate species (Heinbokel 1978, Stoecker \& Evans 1985, Verity 1985, Jonsson 1986). Verity (1985) calculated that assimilation efficiency (growth + respiration/ingestion) did not decrease at high food levels during experiments with herbivorous tintinnids; however, Stoecker \& Evans (1985) observed undigested phytoplankton cells in the fecal material of ciliates feeding at high food concentrations. This suggests that digestion may, in fact, be less efficient when food is very abundant. Lower assimilation efficiencies at high food levels have been reported for the herbivorous copepod Calanus pacificus (Landry et al. 1984), although long acclimation times ( $>1$ wk) apparently are necessary for the required changes in digestive enzyme activity to occur (Hassett 1986).

Increased GGEs at low food concentrations mean that transfer of material from phytoplankton to higher trophic levels is most efficient when food is scarce. By the same token, nutrient regeneration by grazers will be less efficient at low food concentrations. Changes in digestive efficiency, which may underlie GGE variation, indicate that the composition of fecal material produced by grazers can vary depending on their feeding regime.

\section{CONCLUSIONS}

The herbivorous dinoflagellate Gymnodinium sp., isolated from Station P in the open subarctic Pacific, reached maximum growth rates at relatively low food levels and grew rapidly even at low phytoplankton carbon concentrations. This was apparently due to the species' ability to feed effectively at these low concentrations: maximum volume-specific clearance and carbon-specific ingestion rates were high, and maxima were reached at low food levels. Increased GGE may also contribute to rapid growth rates at low phytoplankton concentrations.

Gymnodinium was able to feed on phytoplankton species similar in size and taxonomy to those found at Station P (Booth et al. 1982, Booth 1988). Depending upon the fraction of total phytoplankton biomass available to these grazers in the field, they may be capable of growth rates as high as those reported for Station $\mathrm{P}$ phytoplankton species. Threshold feeding behaviors and preferential grazing such as exhibited by Gymnodinium feeding on Synechococcus may provide a refuge from grazing for certain algal species, permit- ting them to reach a relatively high concentration before being grazed to low levels. Maximum volumespecific clearance rates for Gymnodinium were as high or higher than comparable rates for herbivorous ciliates, suggesting that heterotrophic dinoflagellates have the potential to be major consumers of phytoplankton in marine systems.

Acknowledgements. I thank the members of the SUPER program, in particular B. Frost, for encouragement and support. D. Gifford assisted with isolation of Station P protists; D. Montagnes and F. J. R. Taylor gave taxonomic advice. The manuscript was greatly improved by the comments of $E$. Lessard and an anonymous reviewer. This research was supported by N.S.F. grant OCE 86-13621 to B. W. Frost.

\section{LITERATURE CITED}

Banse, K. (1990). Does iron really limit phytoplankton production in the offshore subarctic Pacific? Limnol. Oceanogr 35: $772-775$

Bjørnsen, P. K., Kuparinen, J. (1991). Growth and herbivory by heterotrophic dinoflagellates in the Southern Ocean. studied by microcosm experiments. Mar. Biol. 109. $397-405$

Booth, B. C. (1988). Size classes and major taxonomic groups of phytoplankton at two locations in the subarctic Pacific Ocean in May and August, 1984. Mar. Biol. 97: 275-286

Booth, B. C., Lewin, J., Lorenzen, C. J. (1988). Spring and summer growth rates of subarctic Pacific phytoplankton assemblages determined from carbon uptake and cell volumes estimated using epifluorescence microscopy. Mar. Biol. 98: 287-298

Booth, B. C., Lewin, J., Norris, R. E. (1982). Nanoplankton species predominant in the subarctic Pacific in May and June 1978. Deep-Sea Res. 29: 185-200

Buck, K. R., Bolt, P. A., Garrison, D. L. (1990). Phagotrophy and fecal pellet production by an athecate dinoflagellate in Antarctic sea ice. Mar. Ecol. Prog. Ser. 60: 75-84

Caron, D. A., Goldman, J. C. (1990). Protozoan nutrient regeneration. In: Capriulo, G. M. (ed.) Ecology of marine protozoa. Oxford Univ. Press, New York. p. 283-306

Cuhel, R. L., Waterbury, J. B. (1984). Biochemical composition and short term nutrient incorporation patterns in a unicellular marine cyanobacterium, Synechococcus (WH7803). Limnol. Oceanogr. 29: 370-374

Dodge, J D., Lee, J. J. (1985). Order 2. Dinoflagellida Butschli, 1885. In: Lee, J J., Hutner, S. H., Bovee, E. C. (eds.) An illustrated guide to the protozoa. Society of Protozoologists, Lawrence, Kansas, p. 22-41

Eppley, R. W. Holmes, R. W., Strickland, J. D. H. (1967). Sinking rates of marine phytoplankton measured with a fluorometer. J. exp. mar. Biol. Ecol. 1: 191-208

Evans, G. T., Parslow, J. S. (1985). A model of annual plankton cycles. Biol. Oceanogr. 3: 327-347

Fenchel, T (1980). Suspension feeding in ciliated protozoa: functional response and particle size selection. Microb. Ecol. 6: $1-11$

Fenchel, T (1982). Ecology of heterotrophic microflagellates I. Some important forms and their functional morphology. Mar. Ecol. Prog. Ser. 8: 211-223

Frost, B. W. (1972). Effects of size and concentration of food particles on the feeding behavior of the marine planktonic 
copepod Calanus pacificus. Limnol. Oceanogr 17 : $805-815$

Frost, B. W. (1975). A threshold feeding behavior in Calanus pacificus. Limnol. Oceanogr. 20: 263-266

Frost, B. W. (1987). Grazing control of phytoplankton stock in the open subarctic Pacific Ocean: a model assessing the role of mesozooplankton, particularily the large calanoid copepods Neocalanus spp. Mar. Ecol. Prog. Ser. 39: 49-68

Gaines, G. (1988). Feeding and reproduction of heterotrophic dinoflagellates. In: Burkill, P. H., Reid, P. C. (eds.) NATO ASI: Protozoa and their role in marine processes. Workshop abstract. Plymouth Marine Laboratory. Plymouth, UK

Gaines, G., Elbrächter, M. (1987). Heterotrophic nutrition. In: Taylor, F. J. R. (ed.) The biology of dinoflagellates. Blackwell Scientific, Oxford, p. 224-268

Garrison, D. L., Buck, K. R. (1989). Protozooplankton in the Weddell Sea, Antarctica: abundance and distribution in the ice-edge zone. Polar Biol. 9: 341-351

Gifford, D. J. (1985). Laboratory culture of marine planktonic oligotrichs (Ciliophora, Oligotrichida). Mar. Ecol. Prog. Ser. 23: 257-267

Gifford, D. J. (1988). Impact of grazing by microzooplankton in the northwest arm of Halifax Harbor, Nova Scotia. Mar. Ecol. Prog. Ser. 47: 249-258

Goldman, J. C., Caron, D. A. (1985). Experimental studies on an omnivorous microflagellate: implications for grazing and nutrient regeneration in the marine microbial food chain. Deep-Sea Res. 32: 899-915

Goldman, J C. Dennett, M. R. (1990). Dynamics of prey selection by an omnivorous flagellate. Mar. Ecol. Prog Ser. 59: 183-194

Goldman, J. C., Dennett, M. R., Gordin, H. (1989). Dynamics of herbivorous grazing by the heterotrophic dinoflagellate Oxyrrhis marina. J. Plankton Res. 11. 391-407

Hansen, P. J. (1991). Quantitative importance and trophic role of heterotrophic dinoflagellates in a coastal pelagial food web. Mar. Ecol. Prog. Ser 73: 253-261

Hassett, R. P. (1986). The effect of feeding history on the feeding behavior of Calanus pacificus. Ph.D. thesis, University of Washington

Heinbokel, J. F. (1978). Studies on the functional role of tintinnids in the Southern California Bight. I. Grazing and growth rates in laboratory cultures. Mar. Biol. 47: 177-189

Jacobson, D. M. (1987). The ecology and feeding behavior of thecate heterotrophic dinoflagellates. Ph.D. thesis, Massachusetts Institute of Technology and Woods Hole Oceanographic Institution

Jacobson, D. M. (1988). Growth and feeding rates of Protoperidinium. In: Burkill, P. H., Reid, P. C. (eds.) NATO ASI: Protozoa and their role in marine processes. Workshop abstract. Plymouth Marine Laboratory, Plymouth, UK

Jacobson, D. M., Anderson, D. M. (1986). Thecate heterotrophic dinoflagellates: feeding behavior and mechanisms. J. Phycol. 22: 249-258

Jonsson, P. R. (1986). Particle size selection, feeding rates and growth dynamics of marine planktonic oligotrichous ciliates (Cilophora: Oligotrichina). Mar. Ecol. Prog. Ser. 33: 265-277

Landry, M. R., Hassett, R. P., Fagerness, V., Downs, J., Lorenzen, C. J. (1984). Effect of food acclimation on assimilation efficiency of Calanus pacificus. Limnol. Oceanogr. 29: $361-364$

Lessard, E. J. (1984). Oceanic heterotrophic dinoflagellates: distribution, abundance, and role as microzooplankton Ph.D. thesis, University of Rhode Island

This article was presented by E. \& B. Sherr, Corvallis, Oregon, USA
Lessard, E. J. (1991). The trophic role of heterotrophic dinoflagellates in diverse marine environments. Mar. microb. Fd Webs 5: 49-58

Lessard, E. J., Swift E. (1985). Species-specific grazing rates of heterotrophic dinoflagellates in oceanic waters, measured with a dual-label radioisotope technique. Mar Biol. 87 $289-296$

Martin, J. J., Broenkow, W. W., Fitzwater, S. E., Gordon, R. M. (1990). Yes, it does: a reply to the comment by Banse. Limnol. Oceanogr. 35: 775-777

Miller, C. B., SUPER group (1988). Lower trophic level production dynamics in the oceanic subarcic Pacific Ocean Bull. Ocean Res. Inst. Univ. Tokyo 26: 1-26

Parslow, J. S., Doucette, G. J., Taylor, F. J R., Harrison, P. J. (1986). Feeding by the zooflagellate Pseudobodo sp. on the picoplanktonic prasinomonad Micromonas pusilla. Mar. Ecol. Prog. Ser. 29: 237-246

Rassoulzadegan, F. (1982). Dependence of grazing rate, gross growth efficiency and food size range on temperature in a pelagic oligotrichous ciliate Lohmaniella spiralis Leeg. fed on naturally occurring particulate matter. Ann. Inst. océanogr., Paris 58 (S): 177-184

Scott, J. M. (1985). The feeding rates and efficiencies of a marine ciliate, Strombidium sp., grown under chemostat steady-state conditions. J. exp. mar Biol. Ecol. 90: $81-95$

Shapiro, L. P., Haugen, E. M., Carpenter, E. J. (1989). Occurrence and abundance of green-fluorescing dinoflagellates in surface waters of the Northern Atlantic and Northwest Pacific Oceans. J. Phycol. 25: 189-191

Sherr, E. B., Sherr, B. F., McDaniel, J. (1991). Clearance rates of $<6 \mu \mathrm{m}$ fluorescently labeled algae (FLA) by estuarine protozoa: relative grazing impact of flagellates and ciliates. Mar Ecol. Prog. Ser. 69: 81-92

Smetacek, V. (1981). The annual cycle of protozooplankton in the Kiel Bight. Mar Biol. 63: 1-11

Stoecker, D. K., Cucci, T L., Hulbert, E. M., Yentsch, C. M. (1986). Selective feeding by Balanion sp. (Ciliata: Balanionidae) on the phytoplankton that best support its growth J. exp. mar. Biol. Ecol. 95: 113-130

Stoecker, D. K., Davis, L. H., Provan, A. (1983). Growth of Favella sp. (Ciliata: Tintinnina) and other microzooplankters in cages incubated in situ and comparison to growth in vitro Mar. Biol. 75: 293-302

Stoecker, D. K., Evans, G. T (1985). Effects of protozoan herbivory and carnivory in a microplankton food web. Mar. Ecol. Prog. Ser. 25: 159-167

Strathmann, R. R. (1967). Estimating the organic carbon content of phytoplankton from cell volume or plasma volume. Limnol. Oceanogr. 12: 411-418

Strom, S. L., Welschmeyer, N. A. (1991). Pigment-specific rates of phytoplankton growth and microzooplankton grazing in the open subarctic Pacific Ocean. Limnol. Oceanogr. 36: 50-53.

Taylor, F. J. R., Waters, R. E. (1982). Spring phytoplankton in the subarctic North Pacific Ocean. Mar. Biol. 67: 323-335

Verity, P. G. (1985). Grazing, respiration, excretion and growth rates of tintinnids. Limnol. Oceanogr. 30: $1268-1282$

Verity, P. G. (1991). Measurement and simulation of prey uptake by marine planktonic ciliates fed plastidic and aplastidic nanoplankton. Limnol. Oceanogr. 36: 729-750

Weisse, T., Scheffel-Möser, U. (1990). Growth and grazing loss rates in single-celled Phaeocystis sp. (Prymnesiophyceae). Mar. Biol. 106: 153-158 